\title{
LA VIOLENCIA GRATUITA Y EL PODER DE LO FALSO EN CÉSAR AIRA
}

\author{
Irene Depetris Chauvin \\ ireni22@gmail.com \\ UBA - CONICET
}

\section{RESUMEN / ABSTRACT}

El impacto del discurso de la publicidad, la revolución del espectáculo y el consumo masivo que hicieron de la cultura juvenil una estética del mercado son algunos aspectos asociados a las reformas neoliberales que recoge La Prueba (1992), novela de César Aira que sigue las derivas de tres jóvenes porteñas. En esta ficción la publicidad es una herramienta de la cultura de masas para crear un espacio y una lógica de consumo donde el sujeto funciona a partir de las leyes establecidas por el mercado. Desde una conceptualización deleuziana del simulacro, este trabajo analiza cómo la novela de Aira expone los mecanismos de funcionamiento del simulacro, al mismo tiempo que los subvierte. Partiendo del deseo comodificado del espectáculo, las jóvenes de La Prueba repiten la retórica del simulacro pero asumen toda la potencialidad de lo falso, al operar un desplazamiento de los elementos recibidos. De esta manera, mediante la violencia gratuita y la simulación, las jóvenes exponen el potencial del simulacro para relacionarnos con lo no pensado y no representado en la cultura contemporánea.

Palabras Clave: César Aira, neoliberalismo, juventud, simulacros.

The impact of advertising and commodity aesthetics, the revolution of spectacle, and massive consumption are expressions of neoliberal reforms analyzed in César Aira's novel La Prueba (1992), which deals with the roams of young female punks in Buenos Aires. In this fiction, advertisement is a tool of pop culture ideology that propels the logic of consumption in which the subject is framed by market laws. The article examines the way in which the novel exposes and subverts mechanisms underlying simulacrum from a deleuzian perspective. Considering the role of commodified desires in the society of spectacle, Aira's punks repeat the rhetoric of simulacrum by reshaping the potential of falsehood, and thus displacing received elements. By means of a performance of violence and simulation, the girls expose the potential of simulacrum by pointing to what has not yet been conceived or represented in contemporary culture.

KEY WORDS: César Aira, neoliberalism, youth, simulacra. 
César Aira es uno de los escritores argentinos contemporáneos más prolíficos. Desde su primera novela, Moreira de 1975, ha publicado más de sesenta títulos que, considerados en su conjunto, conforman una obra marcada tanto por la brevedad como por el exceso. Brevedad, porque sus "novelitas", como Aira mismo las llama, cuentan en promedio con tan solo cien páginas. Exceso, porque sus ficciones son el resultado de una verdadera producción en serie. Durante la década de los noventa, esta producción se multiplicó de manera exponencial, para llegar a un promedio de tres novelas por año, distribuidas por sellos editoriales tan disímiles como los multinacionales Emecé y Randolph-Mondadori o pequeñas editoriales alternativas como Viterbo, Interzona, Eloísa Cartonera o Mansalva.

Pero el exceso es también uno de imaginación. Las novelas de Aira rompen con los códigos de verosimilitud mediante la violación de todas las reglas del relato realista convencional. En Las vueltas de César Aira, una de las primeras interpretaciones detenidas del conjunto de la obra de Aira, Sandra Contreras señala que casi todas las ficciones de este autor parten de los núcleos del relato popular, la historia de amor y las peripecias de la aventura, pero malogran las expectativas del lector al deconstruir y reconstruir estas modalidades narrativas tradicionales, mezclando la fábula, el humor, la paradoja, la reflexión teórica y el absurdo (13). La influencia de los motivos y los códigos del videoclip y de la televisión es también clave para entender el desarrollo espectacular de las tramas: en las novelas de Aira los eventos se suceden a un ritmo vertiginoso que propulsa un desvío progresivo del realismo y hace caer los relatos en el delirio apocalíptico característico de los finales ${ }^{1}$.

Al igual que otras escrituras postmodernas, que se construyen a partir del pastiche, podría considerarse el delirio de la ficción aireana como el resultado de la excesiva intermedialidad con los discursos de los medios de comunicación masiva. Sin embargo, en los últimos años, diversas intervenciones críticas han ofrecido otras explicaciones para el absurdo aireano señalando el rescate y la transposición literaria de los procedimientos vanguardistas que su obra manifiesta (Montaldo; Contreras; Speranza). En su estudio sobre la

\footnotetext{
La influencia del cine catástrofe de clase B es evidente en los finales apocalípticos de las novelas de Aira: "Cuando [los libros recientes de Aira] se aproximan al final, aceleran, los componentes de la narración comienzan a combinarse cada vez con una avidez más desesperada y la trama a apretarse, como si quisiera alcanzar un estado de máxima densidad o se pretendiera producir una suerte de bombardeo de partículas narrativas que arrastrara al lector hasta la apoteosis del final" (Reinaldo Laddaga 2001, 46).
} 
narrativa de Aira, la crítica Sandra Contreras sostiene que este autor utiliza los procedimientos creativos basados en el azar y establece el "continuo" como central a su poética (Contreras 21). Este gesto de la "huida hacia adelante", que supone continuar escribiendo sin nunca volver atrás para corregir o para respetar la coherencia de la trama, instala el "imperfeccionismo" como una clave para entender la obra de Aira. En líneas similares, situando la narrativa de Aira en relación con el surrealismo, Graciela Montaldo se detiene en su concepción de obra como "adefesio" y de escritor como "idiota" para encontrar la radicalidad de Aira en su planeada "improductividad" $(308)^{2}$. También en diálogo con las poéticas vanguardiastas, Graciela Speranza toma de Georges Bataille la categoría de "lo informe" como herramienta conceptual para entender la obra de Aira, y el "continuo" como su fuerza operativa, a la vez que señala la fuerte influencia del recurso del ready-made de Marcel Duchamp en sus procedimientos narrativos ${ }^{3}$.

Imperfeccionismo, improductividad, radicalidad. Antes que una economía comunicativa, la narrativa de Aira presenta una noción de "gratuidad". Las tramas de las novelas resultan excesivas porque subordinan el sentido a la "expansión" textual. Pero el delirio de la narrativa aireana, su exceso, permite dar cuenta también de otro sentido de lo radical. Más allá de su gesto vanguardista, en este artículo me interesa detenerme en una de las primeras novelas de Aira que sigue las derivas de los jóvenes de la clase media y su relación con un consumo espectacular. Publicada en 1992, La Prueba revela un uso alternativo del simulacro, lo que posibilita pensar un sentido también

2 Los finales precipitados y catastróficos suponen también la dilapidación de todo el capital narrativo acumulado a lo largo del relato. Graciela Montaldo ha interpretado este gesto, junto con el de "la huida hacia adelante", en términos de una improductibilidad radical de la literatura. Según la crítica, las narrativas de Aira son máquinas solteras y antiinstitucionales que funcionan como monstruos: su carácter único, su idiotismo, no producen nada $(2005,153)$.

Aira mismo ha contribuido a esta línea de interpretación con diversos artículos en donde sostiene que su función como escritor-artista es inventar mecanismos que produzcan las obras de arte por sí mismos. Para señalar la importancia del azar como procedimiento, Aira menciona la figura del músico norteamericano John Cage, cuya obra Music of Changes fue creada mediante los hexagramas del I Ching. También el artista plástico Duchamp y su concepto de 'ready-made' se presenta en toda la obra de Aira, quien trabaja a partir de los materiales de la cultura baja o de clase $\mathrm{B}$, los códigos de la televisión, el relato popular, los clichés, combinados de manera azarosa y delirante con otros registros de la cultura alta. Los artículos más importantes en donde Aira habla de sus operaciones conceptuales con la literatura son "Ars narrativa" (1994), "La innovación" (1995), "La nueva escritura" (1998) y "Dos notas sobre Moby Dick" (2001). 
alternativo de la subjetividad. Escrita desde el horizonte del espectáculo contemporáneo, en esta novela dos jóvenes punks repiten imágenes mediáticas, pero las performances de violencia que éstas protagonizan suponen una repetición desplazada de esos mismos elementos preconstituidos que lleva a una desestabilización del simulacro. La violencia y la performance de la repetición del simulacro posibilitan un movimiento de devenir en la aparente autoidentidad de la imagen familiar. Antes que la repetición serial y vacía de las apariencias externas de un modelo distante, la apropiación del simulacro en Aira es una afirmación de la posibilidad misma de lo diferente, de un cuerpo monstruoso: el movimiento constitutivo de una subjetividad en exceso.

\section{TERRITORIOS Y SIMULACROS DE LOS AÑOS NOVENTA}

El pensamiento 'marca' la diferencia, pero la diferencia es el monstruo. Gilles Deleuze, Diferencia y repetición

Si bien los textos de César Aira se alejan de una descripción realista de la cotidianeidad, sus tramas se asientan plenamente en el territorio urbano de una Buenos Aires permeada por los mecanismos económicos y culturales de un capitalismo globalizado. Referidos a través de estereotipos mediáticos, los motivos de la nueva pobreza y la precarización del trabajo producto de las políticas neoliberales permean las ficciones de Aira. La guerra de los gimnasios (1993), La mendiga (1998), La villa (2001) y Un sueño realizado (2001) atraviesan la geografía urbana estratificada, escenario del encuentro entre jóvenes de clase media y sujetos desplazados por el sistema ${ }^{4}$. La focalización en los jóvenes de clase media sirve para poner de relieve la ambigua posición de la Argentina dentro del capitalismo globalizado. También las lesbianas punks de La Prueba (1992) sostienen un fuerte vínculo con la cultura de consumo y la cultura mediática, pero su comportamiento revela la posición periférica de la Argentina dentro de la estructura económica de poder global ${ }^{5}$.

\footnotetext{
$4 \quad$ Para una consideración sobre la representación del espacio urbano en la narrativa de Aira, véase Young.

En "Territorios del presente", Josefina Ludmer plantea que después de 1990 se ven nítidamente otros territorios y sujetos, otras temporalidades y configuraciones narrativas, otros mundos que no reconocen moldes tradicionales y que trazan otras fronteras al absorber,
} 
En un sugerente artículo que discute el motivo del consumo fantástico, Dierdra Reber plantea que Aira establece una distancia crítica respecto de éste, ya que sus narrativas presentan subjetividades y afectos contrarios al sujeto racional cartesiano demandado por el capitalismo (395). Para dar cuenta de esta nueva subjetividad, Reber sostiene la existencia de una oposición entre la virtualidad de las imágenes recibidas por los medios de comunicación masivos, que serían ontológicamente falsas, y el conocimiento adquirido a través de una experiencia corporal (338). Aquí me permito sugerir otra interpretación sobre la presencia de lo virtual en Aira. Si consideramos las novelas editadas en los años noventa, no existe tal dicotomía que desacredite la virtualidad para rescatar la materialidad. En estos textos, no solo los protagonistas repetidamente refieren al mundo a partir de nociones recibidas y representadas virtualmente en los medios, sino que el propio armado de las tramas da cuenta de una penetración del universo realista construido en el interior de lo televisivo ${ }^{6}$.

Antes que establecer una oposición tajante entre fenómenos materiales e imágenes virtuales, sugiero que las ficciones aireanas de los noventa trabajan a partir de una contaminación entre los dos niveles. Las jóvenes de La Prueba protagonizan performances de violencia gratuita que provocan una apertura de lo existente a partir de una actualización de lo posible. Partiendo de la repetición de estereotipos massmediáticos y renunciando a prescribir un curso determinado de acción, los textos afirman una lógica del azar que libera a la juventud hacia desarrollos de la subjetividad que se manifiestan en violencia y deformidad de los cuerpos.

contaminar y desdiferenciar lo separado y opuesto $(2004,107)$. El movimiento de contaminación y desdiferenciación es clave para entender a los jóvenes de clase media presentes en la narrativa de Aira. Estos se presentan como subjetividades en el límite que funcionan en el adentroafuera. Los textos mismos llevan la marca de esa contaminación o desdiferenciación no solo en la construcción de los personajes, sino también en el nivel de las tramas, la construcción de las voces y en las adscripciones de género.

Jesús Montoya Juárez divide la obra de Aira en un "corpus canónico”, formado por las novelas editadas en los años ochenta como Ema la cautiva, La liebre o Una novela china, que se dejan leer como narrativas nacionales, reescrituras de la historia o literatura de viajes, y que se diferencian de 'novelitas' publicadas en los noventa, entre las que se encuentran $L a$ guerra de los gimnasios, La serpiente, Yo era una chica moderna, La mendiga, Haikus, Las noches deflores. Estas últimas formarían parte de una "serie b", en la que el procedimiento de la producción masiva de los textos se acompaña del uso masivo de la cultura de masas (53). 
Los relatos de Aira ofrecen una mirada sobre la sociedad contemporánea y sus fenómenos de consumismo, escapismo, globalización e hiperrealidad, pero, más allá de las referencias a estos aspectos en la diégesis de los relatos, los textos presentan una dinámica de lo actual y lo virtual que invita a reconsiderar el lugar del simulacro como la forma en que se organiza nuestra experiencia. Para Jean Baudrillard (2005), en la contemporaneidad los simulacros ya son "la generación por los modelos de algo real sin origen ni realidad: hiperreal. El territorio ya no precede al mapa ni lo sobrevive. En adelante será el mapa el que preceda al territorio - precesión de simulacros-y el que lo engendre" (10). Lo que se genera, entonces, según Baudrillard, es una "sustitución de lo real por los signos de lo real" (11). Esta noción del simulacro, como la repetición serial de las apariencias externas de un modelo distante, prevalece en los análisis contemporáneos de la cultura de masas. Al enfatizar la noción de copia degradada, la lectura de Baudrillard revela un sentimiento nostálgico por un viejo sentido de realidad. Por el contrario, en lugar de pensar el simulacro como una representación vacía o fallida, Gilles Deleuze trabaja sobre la posibilidad que el simulacro ofrece en tanto "asegura un hundimiento universal, pero como acontecimiento positivo y gozoso, como defundamento" (1994: 306) ${ }^{7}$.

Esta reconsideración deleuziana del simulacro deja de interpretar la repetición en términos de su distancia respecto de una identidad fundadora, o como reproductora de lo dado, para entenderla como el retorno de la diferencia. La repetición rompe con el modelo de la representación: no es la vuelta de algo que ya ha sido, sino la creación de lo nuevo. En este sentido, la simulación se presenta como parte de un movimiento constitutivo, como la expresión del poder transformador de lo falso donde de la repetición

\footnotetext{
Deleuze desarrolló su concepto de simulacro principalmente en Diferencia y repetición y Lógica del sentido. En el ensayo "Simulacro y filosofía antigua" recupera la reversión nietzscheana del sistema de valores inherente en la jerarquía platónica de original y copia. En su concepción del simulacro la dirección de la evaluación se invierte: las diferencias se destacan por sobre las equivalencias, las apariencias por sobre las esencias. Así, la simulación es evaluada positivamente: "El simulacro no es una copia degradada; oculta una potencia positiva que niega el original, la copia, el modelo y la reproducción. [...] El simulacro hace caer bajo la potencia de lo falso (fantasma) a lo Mismo y lo Semejante, el modelo y la copia. Hace imposible el orden de las participaciones, la fijeza de la distribución y la determinación de la jerarquía. Instaura el mundo de las distribuciones nómadas y de las anarquías coronadas" (Lógica del sentido 1994, 263-7).
} 
desplazada de las figuras de lo dominante puede crear una nueva sensibilidad ya no necesariamente legitimada por esas verdades ${ }^{8}$.

Es desde esta lectura subversiva del concepto de simulacro que planteo que el "exceso" característico del delirio aireano refiere a una operación de sobrecodificación que vuelve el simulacro contra sí mismo. Para ilustrar estos aspectos, en la siguiente sección analizo la violencia de las punks de $L a$ prueba como una resistencia a las categorías de la sociología de la juventud y al flujo espectacular de imágenes y mercancías. Por último, en el apartado final, evalúo el uso particular de los motivos y técnicas de los medios de comunicación, la importancia de la repetición desplazada de las figuras de lo dominante y el poder de lo falso, presentes en La prueba, como formas críticas de participación en la esfera visual de la contemporaneidad.

\section{LA JUVENTUD Y LA APROPIACIÓN DEL ESPECTÁCULO EN LA PRUEBA}

La imagen dialéctica es un relámpago esférico que atraviesa el horizonte entero de lo pretérito.

Walter Benjamin

La década de los noventa en la Argentina se prefigura en una imagen: pobladores de los barrios más pobres del conurbano bonaerense invaden supermercados, roban las mercaderías y provocan numerosos destrozos. Curiosamente, las imágenes de los saqueos ocurridos en mayo de 1989 se repitieron, pero magnificadas, durante el estallido social de diciembre del 2001. Nuevamente, en un gesto de la profunda crisis que atravesaba el país, cientos de argentinos irrumpieron en supermercados, causando destrozos y vaciando sus estanterías. Esa vez nadie se preocupó de cubrirse el rostro o de eludir las cámaras de televisión. Ahora saqueadores, comerciantes exhibiendo

\footnotetext{
Para Deleuze es Nietzsche, como pensador del eterno retorno, quien aparece más vinculado a esta noción de simulación. En el eterno retorno, la repetición es la expresión suprema de la voluntad de poder que desea la subversión del mundo de la verdad y la representación. El eterno retorno es, para Deleuze, sólo la repetición de aquello que difiere de sí mismo o, en términos de Nietzsche, la repetición de aquellos seres cuyo ser es el devenir (Diferencia y repetición 126). En "Theatrum Philosophicum" Foucault también recupera el histrionismo de la concepción nietzscheana de simulación.
} 
sus escopetas, políticos y periodistas explicando la situación al mismo tiempo en que esta sucedía, todos coincidían en la pantalla de los televisores. Durante la década de los noventa, fueron los medios de comunicación masiva los que decididamente configuraron esa "zona gris" donde interactúan la vida cotidiana y la violencia, la economía y la política (Auyero).

Pero en los diez años que separan los saqueos fueron las imágenes de la publicidad y los programas de entretenimiento los que monopolizaron las pantallas de los argentinos. Las severas políticas de signo neoliberal, que caracterizaron a la época menemista, provocaron al mismo tiempo un aumento de los niveles de exclusión social y una expansión del consumo hasta entonces nunca conocida ${ }^{9}$. La apertura cambiaria impulsó la desindustrialización y el desempleo, pero también la generalización de la compra a crédito, la invasión de marcas y productos extranjeros exhibidos en los flamantes shopping centers de la ciudad. En Escenas de la vida postmoderna, Beatriz Sarlo describe muy bien cómo la juventud fue el sujeto privilegiado de estos cambios: "El mercado toma el relevo y corteja a la juventud ( ) le ofrece un verdadero folletín hiperrealista que pone en escena la danza de las mercancías frente a los que pueden pagárselas y también frente a esos otros consumidores imaginarios que no pueden comprarlas" (43). Como otro subproducto del mercado capitalista, los medios de comunicación masiva hegemonizaron la organización de la dimensión simbólica del mundo social. En el marco de un empobrecimiento creciente de grandes masas de la población, la sociedad de consumo produjo estilos de vida asociados a lo juvenil. La juventud se

$9 \quad$ El menemismo adviene al poder en la Argentina en 1989 cuando Carlos Saúl Menem fue elegido, principalmente, por amplios sectores populares a partir de su presentación como el heredero de los sueños "justicialistas", aunque terminó haciendo exactamente lo contrario al poner en práctica ideas sociales y económicas neoliberales. En efecto, el modelo económico, social y cultural instalado durante la década del noventa difiere en un todo de la primera, segunda y hasta la tercera presidencia de Juan Domingo Perón. Beatriz Sarlo (1990) tempranamente reconoció el particular estilo de la gestión de Menem. Sus principales rasgos fueron la banalidad, el entendimiento de la política y la diferencia de opiniones como obstáculo para la voluntad presidencial, el discurso cínico y excesivo plagado de hipérboles, la destrucción del mito del 17 de octubre y la idea fiscalista de ciudadanía (1-4). Debido a estas características, en este artículo, al tratar la década de los noventa, utilizaré el término de menemismo, en lugar de peronismo, ya que referir a "menemismo" supone aludir a un régimen neoliberal y a un estilo de hacer política que va en contra de la transparencia, de la independencia de poderes y que promueve una ideología neoconservadora (Wortman 2005). 
convirtió en el consumidor privilegiado y los mitos de la "belleza y felicidad" asociados a lo juvenil configuraron la estética predilecta del mercado.

La ideología del consumismo, cuyo paisaje describe Sarlo, la mediatización de la vida cotidiana y la cultura publicitaria de la "belleza y felicidad" juvenil son el punto de partida de La prueba de César Aira. Esta breve novela, publicada en 1992, trata sobre Marcia, una adolescente virgen, tímida y deprimida, que un día es interpelada en la calle por dos chicas punk que dicen llamarse Mao y Lenin y que pretenden ser lesbianas: “-¿Querés coger?”, le dicen. Un poco a regañadientes, pero llena de curiosidad, Marcia acompaña a estas chicas a un local de comida rápida. En el Pumper las punks intentan seducirla y Marcia intenta entender a esas jóvenes tan diferentes a ellas, acudiendo a lo que conoce: el consumo de los programas de televisión y el rock. La aventura y lo verosímil del relato adquieren un giro inesperado cuando Mao y Lenin deciden darle a Marcia una prueba definitiva de su amor. Se dirigen a un supermercado Disco y, en nombre del "Comando del amor", roban las cajas, incendian el establecimiento y matan a empleados y consumidores con una violencia hiperreal.

En una sugerente lectura de las escenas finales de La prueba, Josefina Ludmer plantea que la violencia extrema de las punks no es otra cosa que "la violencia del consumo y la modernización de los años noventa en la Argentina" $(1999,366)$. Efectivamente, las punks atacan a los consumidores en un supermercado, espacio por excelencia de la sociedad de consumo. Asimismo, Ludmer sugiere que la destrucción se relaciona con la "revolución del espectáculo y la imagen" que también tuvo lugar en esos años, en el contexto de desregulación de los medios de comunicación que operó el gobierno de Carlos Menem. Sin embargo, si Marcia es la destinataria privilegiada de las escenas finales de La prueba es porque ella representa el espectáculo "oficial". La escena del supermercado lo que revela es una apropiación y desestabilización del simulacro de la "belleza y felicidad" de los jóvenes que se sugiere en las primeras páginas de la novela.

Al comienzo de La prueba nos encontramos con Marcia haciendo su paseo habitual desde la escuela a su casa. Lo que ella encuentra cada vez que repite el paseo es la reunión periódica de jóvenes después de la escuela. Desde una posición de relativa exterioridad, Marcia "chocaba con la carga de signos flotantes (...) Ella no lo sentía, o no debería sentirlo, porque era parte del sistema, pero todos esos chicos estaban perdiendo el tiempo. Era el sistema que tenían de ser felices. De eso se trataba, y Marcia lo captaba perfectamente, aunque no podía participar" (8-9). En un artículo en donde 
analiza la subjetividad asociada al consumismo en términos del concepto lacaniano de "goce", Mariana Gómez (2006) plantea que la sociedad menemista fue una auténtica sociedad del espectáculo: el capital se volvió imagen y la exhibición funcionó como mecanismo de relación entre los sujetos. En este contexto, la belleza y la juventud empezaron a operar como plus de goce. Un contexto social caracterizado por la degradación del trabajo y la búsqueda de satisfacción en el ámbito de la vida privada dio lugar a una "cultura del narcisismo". Por ello, el mercado de las marcas [y el consumo de "belleza"] terminaron siendo proveedores de identidad (Uhart 2004). Los años noventa generaron un fetichismo y un exhibicionismo enlazados con un imperativo de "gozar" determinado por las prácticas sociales que sostienen la ideología imperante.

Aunque Marcia no puede participar directamente en el consumo ella sí experimenta y valida el plus de goce del consumo del sistema de belleza y felicidad: desde una distancia relativa ella observa y clasifica con las categorías de una sociología de la juventud muy cercana a los estudios de mercado $^{10}$. Como si fueran productos en un supermercado, Marcia ve a la "gente joven exhibiéndose" como "emblemas de una belleza o de una felicidad" (10-13). El impulso clasificatorio de Marcia vuelve una y otra vez durante su conversación con las punks. Cuando Mao le dice a Marcia que ella y Lenin no son punks, llena de desconcierto Marcia piensa: "Son 'feministas'... fue una pequeña conclusión automática que la desilusionó un poco" (126). Repetidamente, Marcia intenta categorizar a Mao y Lenin en términos del consumo. En un momento, les pregunta si les gusta la música de The Cure o el show del gordo Porcel, pero las punks dicen desconocerlos porque no miran televisión (25). Incluso, cuando Mao se niega a pedir en el mostrador del Pumper algo para consumir, Marcia apunta: "Los punks no hacían consumiciones corrientes. Recordó haberlos visto tomando del pico de botellas de cerveza de litro en los zaguanes" (23). Marcia piensa desde las generalidades de las categorías de la sociología de la juventud y aunque ella no participa del sistema de la "belleza y felicidad", según las punks, ella

10 El concepto de plus-de-goce permite a Lacan explicar una relación con el objeto del que nadie puede gozar verdaderamente: el goce absoluto de un objeto o de otra persona es imposible y vivir significa estar lidiando constantemente con una pérdida o una renuncia de/a ese goce. Esta pérdida del goce es la que nos permite seguir deseando, es parte de la lógica misma del sistema. Marcia es interpelada por los valores comodificados de la juventud que la excluyen como adolescente "rara", sin embargo hay un goce de esa pérdida o renuncia. 
repite un tipo porque está "representando a Liliana", la empleada que trabaja en el Pumper (35).

Según César Barros, en La prueba, Marcia pasa del mundo de las opiniones, los semblantes y las determinaciones ideológicas al mundo de la acción creadora y subjetivadora que le propone el nihilismo activo de Mao y Lenin. Claramente, la transformación del mundo nietzscheana se evidencia en las impresiones de Marcia para quien cada ejercicio de violencia de las punks produce una revelación. En el momento en que Mao insulta a la supervisora del restaurante, para Marcia "fue como si el Pumper hubiera cambiado de naturaleza. No era la primera vez que tenía ese sentimiento desde que las dos chicas se habían dirigido a ella en la esquina de enfrente, menos de un cuarto de hora antes: el mundo se había transformado una y otra vez" (27). Por otro lado, en la novela las punks en sí mismas no representan un mundo esencialmente verdadero, en oposición al mundo de las apariencias y de lo dado de Marcia. Ella también escucha de Lenin y Mao los clichés punk, contraculturales, transgresivos, nihilistas y revolucionarios del "Comando del amor". Como sugiere Patrick O'Connor, las punks de la novela están construidas según los materiales de una tradición estereotipada vinculada al lesbianismo y al cliché de la transgresión y la violencia $(1999,24)$. Entonces, lo que opone la novela no son dos sistemas, sino dos lógicas de operar con ese sistema. La acción de las punks se inicia en la repetición de lo dado -los clichés de "el amor a primera vista" y "la prueba de amor"-pero la violencia opera un desplazamiento de esos elementos. La repetición introduce una diferencia, lo nuevo surge de la repetición desfasada de lo vigente producto del acto como ejercicio creativo de transformación del mundo.

$\mathrm{Al}$ encontrar la dimensión del acto, Marcia recorre el camino de apropiación del deseo comodificado del espectáculo. Esto queda claro antes de la revelación final en el supermercado. La violencia de la interpelación de las punks, cuando se encuentran por primera vez en la calle, le hace apropiarse y experimentar lo dado de una manera diferente: "Unos pasos más y Marcia llegaba al punto de máxima sonoridad. Pero ahora la música había cambiado de sentido. Era como si se hubiera hecho real, cosa que nunca sucedía con la música (...) Por donde iba había grupos juveniles todavía (...) pero ya no eran como antes emblemas de una belleza o de felicidad, sino de otras" (13). Más adelante, de la experimentación intensa de lo dado, Marcia pasa a experimentar el carácter constitutivo del acto. La repetición del cliché de "la prueba", a manos de "El Comando del amor" instaura una diferencia pura: "La belleza y lo distinto estallaban en la noche, y la transformación que producían no era, como las 
anteriores que había creído percibir, la vuelta de página a una nueva versión del mundo, sino la transformación del mundo en mundo" (53).

El mecanismo de la transformación por medio de la repetición desplazada de lo dominante se evidencia en el uso de la frase hecha. En un momento el narrador reflexiona teóricamente:

Hay un viejo proverbio que dice: "Si Dios no existe, todo está permitido". Pero lo cierto es que nunca está permitido todo, porque hay leyes de verosimilitud que sobreviven al Creador. Aún así, la segunda parte del proverbio puede funcionar, es decir, hacerse realidad, al modo hipotético, dando origen a un segundo proverbio sobre el modelo del original: 'Si todo está permitido...'. Este nuevo proverbio no tiene segunda parte. En efecto, si todo está permitido ... ¿qué? (...) Si todo está permitido... todo se transforma" (69).

Si la repetición desplazada del proverbio alumbra el fantástico potencial de transformación que tiene todo, la lógica de transformación se profundiza cuando la narrativa se entrega a una fuerte intermedialidad con regímenes visuales $\mathrm{y}$, en particular, con las técnicas de superposición temporal del videoclip y la deformación de la imagen propia de la animación digital. El carácter de 'contra espectáculo', de apropiación creativa del simulacro, se revela antes de comenzar la acción. Mao, al mando del "Comando del amor", anuncia que "en una hora los sobrevivientes estarán en su casa mirando la televisión" (60). Si durante los noventa la televisión convirtió los hechos sociales y políticos en espectáculos para su consumo, Mao y Lenin se apropian de los mecanismos visuales del simulacro para ofrecerle a Marcia otro espectáculo. La narración adopta una textura cinematográfica de violencia visual expresionista:

La explosión fue inaudita, la onda expansiva un oleaje espeso de polvo de vidrio verde y alcohol inflamado... los movimientos de Mao sobre las cajas se habían hecho de una lentitud sobrenatural (...) Cuando la atacante se alzó, como una moderna Salomé de negro, sostenía con las dos manos de la cabeza de la señora. El espectáculo había atraído la atención general. (...) Mao lanzó la cabeza como una pelota hacia los que gritaban (...) La atmósfera se había enrarecido. El calor del fuego estaba cargado de olores asfixiantes. Toda la materia comestible y bebible del supermercado se trasmitía al aire (...) Los envases de solventes, ceras, lustres, amoníacos, estallaban con hedores irrespirables. Las masas cautivas presionaban por alejarse y pasaban unos por encima de la cabeza de los otros (...) en pleno 
sálvese quien pueda (...) Góndolas enteras empezaban a derrumbarse sobre la gente. Y la cabeza de la señora seguía en el aire, no porque se hubiera detenido en un milagro de levitación post mortem, sino porque había pasado muy poco tiempo (67-68, énfasis mío).

El relato lleva al extremo la velocidad de circulación de las imágenes propias de los medios de comunicación masiva. Todo termina en catástrofe consumida como espectáculo televisivo que transforma a los "clientes y empleados" en "espectadores". El pasaje revela también la combinación de una temporalidad retardada con la velocidad hiperacelerada propia de la tecnología del video. Según Beatriz Sarlo (1994), las imágenes de la publicidad y la televisión, los videojuegos y ciertas películas de clasificación "B" son un "infinito periódico". En cada cambio de canal o de programa termina un ciclo y recomienza otro básicamente igual pero con variantes. Esas imágenes que se presentan unidas en una trama sin historia atrapan e hipnotizan porque lo familiar de las imágenes crea la sensación de "estar en casa", en la casa mental donde habitan tramas parecidas. Sin embargo, en la novela de Aira la intermedialidad con el videoclip devuelve imágenes no familiares:

Una mujer, por ejemplo, un ama de casa de barrio (...) se fundía en su lugar a la vista de sus congéneres que no le prestaban atención. El fuego se había apoderado de la fibra viscosa de su tapado matelasse. La señora se hacía monstruo, pero monstruo bayadera, con una voluptuosidad que durante toda la vida se le había escapado: sus miembros se alargaban, una mano al extremo de un brazo de tres metros reptaba por el suelo, una pierna se enroscaba una y otra vez, innumerable como una cobra Se hacía animal, pero todos los animales al mismo tiempo, animal espectáculo con los barrotes de la jaula saliéndole como espinas de cada repliegue del cuerpo (69-70).

Aquí la apropiación de los mecanismos visuales del simulacro hace posible lo monstruoso. La violencia gratuita de las punks repite las imágenes del espectáculo y las devuelve transformadas. La performance del supermercado no solo transforma la subjetividad de Marcia, sino también la materia misma de los cuerpos en donde lo virtual se concibe como una potencialidad que se realiza en lo actual ${ }^{11}$.

11 En los Diálogos, Deleuze desarrolla la importancia de la distinción entre lo virtual y lo actual en términos de una diferencia de tiempo. Toda imagen actual está inscripta en 
Lo virtual también es real en tanto tiene un efecto en el presente. La imagen tiene cualidades internas que la vuelven performativa; su virtualidad insiste en lo actual. Al comentar el tremendismo de cine de clase B, que caracteriza al final de La prueba, Sandra Contreras señala que la literalización del cliché de "la fuerza del amor" no funciona negativamente para desmantelar los géneros sino como motor del relato (117). Extendería este punto para decir que la exacerbación del cliché y la espectacularidad narrativa no solo ofrecen un comentario sobre el régimen visual del presente, sino que la implosión del final abre el relato hacia una dimensión del futuro. El relato termina con la salida de Mao, Lenin y, a último minuto, de Marcia, del establecimiento. Como si ésta fuera un personaje de una serie de dibujos animados, Marcia deja de observar y sigue a las punks que se habían arrojado contra la vidriera del supermercado y escapan dejando un círculo perfecto en el vidrio. Como en todo apocalipsis, el final es el comienzo de algo, lo virtual se actualiza:

¿Cuánto tiempo había pasado? ¿Cinco minutos en total, desde que interrumpieron en el supermercado? ¡Cuántas cosas habían pasado! (...) reinaba una huída centrífuga, el Big Bang, el nacimiento del universo. Era como si todo lo conocido estuviera alejándose, a la velocidad de la luz, a fundar a lo lejos, en el negro del universo, nuevas civilizaciones basadas en otras premisas. Era un comienzo, pero también era el final (....... y las dos juntas se arrojaban sobre el vidrio del ángulo que daba a la calle... con la fuerza impune del amor (...) El vidrio estalló y el hueco se las llevó limpiamente... dos figuras oscuras sin límites atraídas por la inmensidad del exterior... y el preciso momento en que salían, una tercera sombra se les unió ... tres astros huyendo en el gran giro de la noche... las tres marías que

una constelación de imágenes virtuales. Lo actual se define por el presente que se desarrolla, mientras que lo virtual se define por el pasado que se conserva en ella y que puede activarse en el futuro. Como señala Deleuze, lo virtual no se opone a lo real sino a lo actual; se cristaliza en actualizaciones. Por tanto, posee "una realidad plena, en tanto que virtual" (Deleuze, Diferencia y repetición 2006). Tempranamente, en Los Fantasmas (1990), César Aira sugiere esta relación entre lo virtual y lo actual a partir de las figuras de lo construido y lo no construido. Esta novela de 1990 narra un día en la vida de una adolescente chilena, Patri, que vive con su familia en un lujoso edificio todavía en construcción. En el edifico habitan también fantasmas, que descansan sobre las antenas de televisión, y que solo la adolescente puede ver. De manera similar a los personajes de ficción que la joven sigue en la telenovela de la tarde, los fantasmas representan un cierto espacio liminal, situados en una frontera entre la vida y la muerte, entre lo que está y lo que no está construido. 
todos los niños del hemisferio sur miran hechizados, sin comprender... y se perdieron en las calles de Flores (70-71).

En el pasaje, la forma catastrófica no solo ofrece un comentario sobre la dinámica de superposición de imágenes propia del simulacro de los medios de comunicación, la salida del final puede ser entendida también en función del mesianismo de la imagen propuesto por Walter Bejmanin. En diversos pasajes, Benjamin se refiere a los efectos transformativos de las imágenes en términos de "iluminación profana" y "despertar", expresiones que suponen una noción de ahora, estrechamente vinculada al concepto mesiánico de tiempo, un tiempo siempre presente que irrumpe a través del continuo de la historia para revelar lo no completo, las potencialidades utópicas acumuladas a lo largo del pasado de la humanidad $(1999,253)$. La imagen se convierte en el agente de una transformación utópica ya que supera la separación entre conocimiento y acción. En palabras de Bejamin, en el despertar como intersticio se produce la imagen dialéctica como acción, como relación que es "aquello en donde lo que ha sido se une como un relámpago al ahora en una constelación" ${ }^{12}$. Irónicamente el narrador señala que, al igual que Cristobal Colón, Marcia ha "descubierto un mundo nuevo". Sin embargo, la transformación del mundo en mundo, no culmina con la representación de esa comunidad virtual. El deseo de metamorfosis, y la relación radical que abre hacia el futuro, se concibe en tanto nunca se define ese plus. Las tres marías son astros, figuras sin límites: la apropiación del simulacro abre un espacio para pensar en el futuro como el mundo de todo lo posible.

12 "No es que lo pasado arroje luz sobre lo presente, o lo presente sobre lo pasado, sino que la imagen es aquello en donde lo que ha sido se une como un relámpago al ahora en una constelación. En otras palabras: imagen es la dialéctica en reposo. Pues mientras que la relación del presente con el pasado es puramente temporal, continua, la de lo que ha sido con el ahora es dialéctica: no es un discurrir, sino una imagen [...] en discontinuidad" (Benjamin, Libro de los pasajes 464). 


\section{DE LA REPETICIÓN A LA DESESTABILIZACIÓN DEL SIMULACRO}

Lo virtual posee una realidad plena, en tanto que virtual.

Gilles Deleuze, Diferencia y repetición

Más allá de la mención de elementos o figuras propios del registro de la telenovela, a nivel estructural el trabajo con el pastiche en Aira recicla y trasplanta a la literatura operaciones que practicaran Marcel Duchamp y los dadaístas. La inclusión de objetos y materiales dentro de las artes plásticas se traduce en el relato como frases hechas o clichés. En su taxonomía de los elementos lingüísticos en las novelas de Aira, Norma Carricaburo plantea que, en éstas, las frases provenientes de la oralidad, las marcas del lenguaje mediático o publicitario, las expresiones estereotipadas o lugares comunes de la adolescencia pueden asimilarse al concepto del ready-made, mientras que las citas literarias responden más a la figura del objet trouvé.

De esta manera, las imágenes y los procedimientos de los medios masivos se convierten en un material que sirve para la construcción de un "ready-made verbal". En las artes plásticas el ready-made es una repetición que vacía la repetición mediante el acto irrepetible de crearse ex-nihilo como acción de arte, puro acto de creación en el cual desaparecen, consumados, productor y producto. El ready-made extrae el objeto de la serialidad mercantil que reduce su valor formal a mera equivalencia y expone esa misma nada de la existencia serial del objeto en su plena insignificancia. La obra resultante, entonces, vale como registro de una acción de arte, más que como objeto de arte en sí mismo.

La literatura de César Aira coloca cada frase, motivo, tema y elemento de género como ready-mades en un continuo sin fisuras que al repetirlas convierte las semejanzas en desemejanzas. En otras palabras, el pastiche de Aira opera una transformación: los elementos prefabricados se utilizan para el avance del relato al instaurar una verdadera proliferación del sentido. Pero en la repetición literal de los clichés mediáticos, la narrativa de Aira produce algo más. En la violencia de las lesbianas estereotipadas e hiperreales de $L a$ prueba hay un uso de la imagen que forma parte de una intervención en la economía espectacular contemporánea.

La emergencia de lo que Guy Debord llamó "sociedad del espectáculo" ha supuesto la apertura a nuevas políticas de la imagen. Situados en el dominio del simulacro, ya no es tan importante el valor de verdad de la imagen como los efectos que ésta produce. Teniendo en cuenta la forma emblemática de 
los deseos comodificados del espectáculo postmoderno, el 'proyecto' de la narrativa analizada en este artículo sería volver al simulacro contra sí mismo. Estas narrativas cuestionan la separación entre lo virtual y lo actual que es constitutiva del espectáculo postmoderno. Las imágenes seriales que se repiten, que son apropiadas, en la cultura del simulacro potencialmente son más que meras emanaciones de un mundo espectacular del que los sujetos están separados: las performances de las jóvenes punks de César Aira nos permiten hablar de una "experiencia" del simulacro.

La proliferación de lenguajes mediáticos en los textos es ejemplo de prácticas de simulación. En la repetición, la imagen familiar se transforma en otra cosa: los clichés del "amor a primera vista" y "la prueba de amor" en La prueba convierten el melodrama novelesco en una película de clase B filmada al ritmo del videoclip. Esta práctica de la violencia y la simulación supone actualizar el potencial de la imagen virtual en el acto. De esta manera, la repetición, como eterno retorno de la diferencia, se entiende como un movimiento hacia el futuro en el que es posible también otro tipo de subjetividad.

En las narrativas de Aira, el acto de simulación aparece como subversivo respecto de las verdades e identidades del orden legítimo. En La prueba, al igual que los elementos, las relaciones son reproducidas, desplazadas o transformadas en cada repetición. Si se puede pensar una noción de política en los textos de Aira, ésta no radica en la representación de un sujeto antagónico o marginal respecto del sistema. Más bien, en el acto mismo de la repetición y de la simulación, los personajes proponen la posibilidad de pensar una nueva relación con el propio deseo, uno que, al igual que la subjetividad, nunca se estabiliza sino que está siempre en exceso.

El vínculo entre la potencialidad virtual de los personajes de reinventarse libremente y la potencia virtual de un colectivo es muy débil en la narrativa de César Aira. No obstante, el final de La prueba expone el problema estético y político de la relación con lo que permanece impensado y no representado pero que las figuras del espectáculo postmoderno repiten. Al asumir las repeticiones del simulacro, las jóvenes punks dramatizan una relación con esos otros mundos y formas de vida que todavía no han sido actualizadas. A partir de la repetición en el presente se actualiza lo pasado y se hace posible la dimensión de un futuro. El agujero en el cristal del final de La prueba afirma el débil poder mesiánico de una imagen que se vuelve contra el simulacro del cual proviene, al extraer de lo que parece reconocible la fuerza de lo no pensado. 


\section{BIBLIOGRAFÍA}

Aira, César. La prueba. Buenos Aires: Grupo Editor Latinoamericano, 1992.

"Ars narrativa". Criterion 8 (enero 1994).

"La innovación". Boletín del centro de estudios de teoría y crítica literaria 4 (1995): 22-29.

“La nueva escritura”. La Jornada Semanal. 12 Apr. 1998. <http://www.jornada. unam.mx/1998/abr98/980412/sem-aira.html>.

"Dos notas sobre Moby Dick". Babelia/El País, 12 de mayo de 2001.

Auyero, Javier. La Zona Gris: Violencia Colectiva Y Política Partidaria En La Argentina Contemporánea. Buenos Aires: Siglo XXI editores, 2007.

Baudrillard, Jean. Cultura y simulacro. Karios: Barcelona, 2005.

Benjamin, Walter. Libro de los pasajes. Trad. Rolf Tiedemann. Tres Cantos: Akal Ediciones, 2005.

Poesía y Capitalismo: Iluminaciones II. Trad. Jesús Aguirre. Madrid: Taurus, 1999.

Contreras, Sandra. Las vueltas de César Aira. Rosario: Viterbo, 2002.

Deleuze, Gilles. Diferencia y repetición. Amorrortu: Buenos Aires, 2002.

Lógica del sentido. Paidos: Barcelona, 2005.

Deleuze, Gilles y Félix Guattari. El Anti-Edipo: Capitalismo y esquizofrenia. Trad. Francisco Monge, Barcelona: Paidós, 1985.

Mil mesetas: Capitalismo y esquizofrenia. Trad. José Vázquez Pérez. Valencia: Pre-textos, 1997.

Laddaga, Reinaldo. "Una literatura de la clase media: Notas sobre César Aira". Hispamérica: Revista de Literatura 30.88 (2001): 37-48.

Ludmer, Josefina. "Territorios del presente. En la isla urbana". Pensamiento de los confines. 15 (diciembre 2004): 103-110.

Massumi, Brian. "Realer than Real. The Simulacrum According to Deleuze and Guattari". Copyright 1, 1987.

Montaldo, Graciela. "Una literatura que lo puede todo", Literatura latino-americana do século XXI. Ed. Beatriz Resende. Río de Janeiro: Aeroplano, 2005, 127-139.

Montoya Juárez, Jesús. "Aira y los aireanos. Literatura argentina y cultura masiva desde los noventa". Entre lo global y lo local: La narrativa latinoamericana en el cambio de siglo (1990-2006). Ed. Jesús Montoya Juárez y Ángel Esteban. Vervuert, Iberoamericana, 2008, 51-77.

O’Connor, P J. “Cesar Aira's Simple Lesbians: Passing La Prueba”. Latin American Literary Review. 27.54 (1999): 23-38.

Reber, Dierdra. "Cure for the Capitalist Headache: Affect and Fantastic Consumption in César Aira's Argentine 'Baghdad'”. MLN 122.2 (2007): 371-99.

Sarlo, Beatriz. "Menem." Punto de vista 39 (1990): 1-4.

Speranza, Graciela. "César Aira, literatura ready-made". Fuera de campo: literatura y arte argentinos después de Duchamp. Barcelona: Anagrama, 2006, 289-315. 
Uhart, Carolina. "La mujer en los noventa: Procesos ideológicos, consumo e identidad". Cartografías de la Argentina de los 90. Cultura mediática, política y sociedad. Ed. Mariana Antonelli. Córdoba: Ferreyra editor, 2004.

Wortman, Ana. Pensar las clases medias: consumos culturales y estilos de vida urbanos en la Argentina de los noventa. Ciudad Autónoma de Buenos Aires, Argentina: La Crujía Ediciones, 2003.

Young, Richard. "Buenos Aires and the narration of urban spaces and practices". S. Hart y R. Young. Ed. Contemporary Latin American Cultural Studies. London: Arnold, 300-13. 